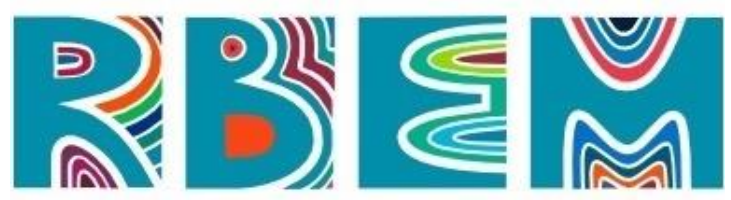

REVISTA BAIANA dE EDUCAÇÃo MATEMÁtICA

ARTIGO

https://doi.org/10.47207/rbem.v2i01.10252

\title{
Influências do Estágio Supervisionado para Professores de Matemática em Início de Carreira - buscando compreender escolhas e características das escolas-campo
}

\author{
SILVA, Ulisses Dias da \\ Universidade Federal do Rio de Janeiro (UFRJ). Doutor em Ensino de Matemática pela Universidade Federal do \\ Rio de Janeiro. ORCID: https://orcid.org/0000-0003-3919-2786. E-mail: ulissesdias@ ufrj.br. \\ OLIVEIRA, Ana Teresa de Carvalho Correa de \\ Universidade Federal do Rio de Janeiro (UFRJ). Doutora em Educação pela Pontifícia Universidade Católica do \\ Rio de Janeiro. ORCID: https://orcid.org/0000-0003-4196-2639. E-mail: atcco@uol.com.br
}

\begin{abstract}
Resumo: Esta pesquisa apresenta o recorte da tese de doutorado do primeiro autor, orientado pela segunda autora, que investiga as influências do estágio curricular supervisionado obrigatório para professores no início de sua carreira. Foram realizadas entrevistas semiestruturadas com 20 sujeitos, selecionados com até três anos de experiência e que atuavam como professores de matemática em escolas regulares da rede pública ou privada de ensino, na educação básica. Com base nas entrevistas, a Análise de Conteúdo foi utilizada como instrumento metodológico para que emergissem quatorze categorias de análise que foram reorganizadas em seis - as escolhas, a escola, o estágio acontecendo, as relações construídas, os sentidos construídos pelos sujeitos e o passado no presente. Este artigo se concentra nos dois primeiros eixos. Concluímos que: i) os estágios divergem significativamente de instituição para instituição; ii) as escolas-campo mais preparadas e com maior acompanhamento possuem impactos mais significativos; iii) é preciso investir em uma maior integração do estágio ao currículo da licenciatura para melhores resultados formativos.
\end{abstract}

Palavras-chave: Estágio Curricular Supervisionado. Escolas-Campo de Estágio. Formação Inicial de Professores de Matemática. Análise de Conteúdo.

\section{Influences of Practicum Experiences for Beginning Teachers - understanding field-schools' possible choices and characteristics}

\begin{abstract}
This research is a first author doctoral thesis' part, advised by the second, aiming to investigate practicum influences for beginning teachers. The research corpus consists of semi structured interviews with 20 subjects, selected for having up to three years of teacher experience and working as mathematics teachers in public/private basic schools. We used Content Analysis for emerge fourteen categories divided in six axes - choices, the school, practicum in practice, relations, subjects' senses and past in present. This article focuses in the first two. We conclude: i) there are many differences between practicum in different institutions; ii) better prepared field-schools have greater formative impacts; iii) it should be invested in a deeper integration between practicum and graduation course for better formative results.
\end{abstract}

Keywords: Practicum. Practicum Field-Schools. Initial training of Mathematics Teachers. Content Analysis. 


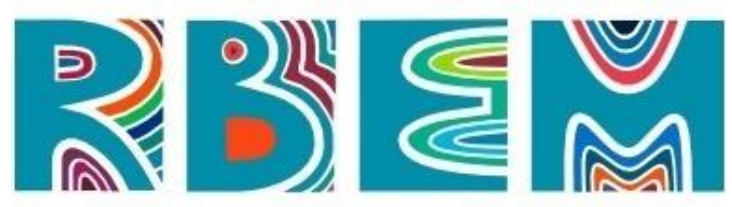

\title{
Influencias de la experiencia de pasantía supervisada para maestros recién graduados: comprensión de las posibles opciones y características de las escuelas de campo
}

\begin{abstract}
Resumen: Esta investigación presenta el recorte de la tesis doctoral del primer autor, guiado por el segundo autor, quien investiga las influencias de la pasantía curricular supervisada obligatoria para docentes al inicio de su carrera. Se realizaron entrevistas semiestructuradas con 20 sujetos, seleccionados con hasta tres años de experiencia y que se desempeñaron como profesores de matemáticas en escuelas públicas o privadas, en educación básica. A partir de las entrevistas, el Análisis de Contenido se utilizó como herramienta metodológica para emerger catorce categorías de análisis que se reorganizaron en ejes: las elecciones, la escuela, el proceso de pasantía, las relaciones construidas, los significados construidos por los sujetos y el pasado en el regalo. Este artículo se centra en los dos primeros ejes. Concluimos que: i) las pasantías difieren significativamente de una institución a otra; ii) las escuelas de campo más preparadas y monitoreadas tienen impactos más significativos; iii) es necesario invertir en una mayor integración de la pasantía en el plan de estudios de grado para obtener mejores resultados formativos.
\end{abstract}

Palavras-Clave: Pasantía supervisada. Escuelas de campo de prácticas. Formación inicial de profesores de matemáticas. Análisis de contenido.

\section{Introdução}

O Estágio Curricular Supervisionado Obrigatório (doravante nomeado apenas de estágio) é uma das etapas mais importantes da formação inicial de professores de Matemática. Porém, a despeito da legislação mais recente, que preconiza 400 horas dedicadas ao estágio no curso de licenciatura (BRASIL, 2015), existem diversos modelos de provisão de estágio, com base nos currículos dos cursos de licenciatura, com um papel maior ou menor para o estágio - e para a prática.

A literatura aponta para uma posição inferiorizada do estágio como componente da licenciatura em Matemática, conforme alguns autores (por exemplo, GATTI; NUNES, 2009; MOREIRA, 2012) que observam que, ao relegar a prática a um local secundário, explicitamente se valoriza um tipo de conhecimento - teórico, matemático - na formação inicial docente. Porém, valorização da teoria "se traduz em espaços desiguais de poder na estrutura curricular, atribuindo menor importância à carga horária denominada 'prática'” (PIMENTA; LIMA, 2012, p. 34).

A desimportância do estágio se mostra visível também na quantidade pequena de pesquisas sobre o tema na área de educação matemática. Lopes et al (2017) identificam um 


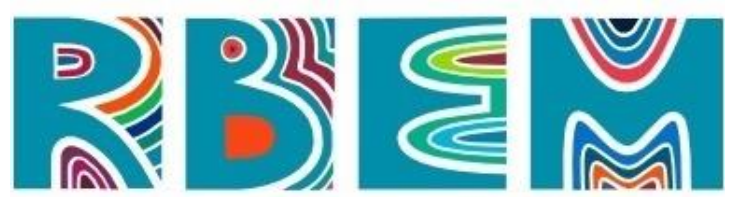

REVISTA BAIANA DE EDUCAÇÃO MATEMÁTICA

total de 20 trabalhos com foco no estágio curricular supervisionado em um mapeamento de todas as Teses e Dissertações de programas strictu sensu sobre o tema estágio supervisionado nas licenciaturas em Matemática, defendidas entre 2001 e 2012. Esse artigo é parte do projeto Mapeamento e estado da arte do professor que ensina matemática (FIORENTINI et al, 2016).

Com base nisso, podemos perguntar, do ponto de vista dos professores que estão começando a trabalhar, qual é o papel e a importância do estágio para a prática atual como docentes? Mais especificamente, quais são os limitantes e características do estágio supervisionado? Este artigo tem como objetivo dar uma contribuição a estes questionamentos.

Para isto, o artigo está organizado nas seguintes seções: quem somos, de onde falamos e porque dizemos o que estamos dizendo, que é composto de apontamentos sobre os autores e aspectos metodológicos que consideramos cruciais para compreender o escopo da pesquisa; quem fala conosco, que aborda o marco teórico básico no qual este trabalho está ancorado e com quem dialoga; vozes que emergem dos dados, em que apresentamos a análise dos dados da pesquisa; e ecos, nos quais apresentamos conclusões e futuros apontamentos.

\section{Quem somos, de onde falamos e porque dizemos o que estamos dizendo?}

Esta é uma pesquisa qualitativa, baseada em entrevistas realizadas com sujeitos que estão trabalhando, rememorando as experiências - ainda relativamente recentes - de quando estavam cursando sua licenciatura. Porém, antes de falar sobre isto, é importante evidenciar quem pergunta e de onde pergunta. Isto porque, muito embora a pesquisa tenha sido realizada com base nos critérios de inquérito estabelecidos e com o acompanhamento do comitê de ética em pesquisa ${ }^{1}$, conhecer essas indagações ajudará o leitor a compreender o interesse dos autores nas questões de pesquisa abordadas neste trabalho.

Ulisses, primeiro autor desta pesquisa é professor da Universidade Federal do Rio de Janeiro desde 2011, atuando no Colégio de Aplicação, com turmas de ensino básico e na supervisão de estágio. Esta pesquisa é um recorte de sua Tese de Doutorado (SILVA, 2019), orientada pela segunda autora. Ana Teresa é professora da Faculdade de Educação da

\footnotetext{
${ }^{1}$ Aprovado pelo Comitê de Ética em Pesquisa da Universidade Federal do Rio de Janeiro, com CAAE 87002218.7.0000.5257.
} 


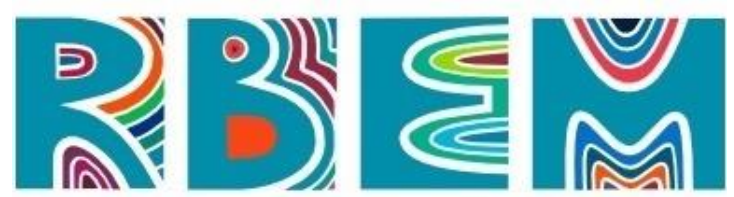

REVISTA BAIANA DE EDUCAÇÃO MATEMÁTICA

Universidade Federal do Rio de Janeiro e atua, entre outras funções, como professora orientadora de estágio desta instituição. Sendo assim, nós autores temos uma atuação profissional próxima, trabalhando em parceria na mesma universidade, com o estágio, mas com olhares complementares: Ulisses atua na escola-campo e Ana Teresa na licenciatura. Falamos, portanto, como parceiros de trabalho, mas também como orientadora e orientando de doutorado, com um objetivo de pesquisa comum. Falamos também como pesquisadores da mesma universidade, situada no Estado do Rio de Janeiro.

E este é um recorte importante. O Estado do Rio de Janeiro possui diversas Instituições de Ensino Superior (IES) que formam professores de Matemática, o que permite uma comparação das experiências de estágio que são proporcionados por elas, como veremos. Mas isto não significa que este recorte reflita como o estágio é provido de maneira nacional. Outras IES, com outras culturas curriculares e com pesos diferenciados em relação à prática e ao estágio, proporcionam experiências diferentes. Cyrino; Passerini (2009), Feldkercher (2011) e Gonçalves Júnior (2016) são exemplos de trabalhos que enfocam experiências de estágio que não se aproximam das que serão descritas neste trabalho. Porém, acreditamos que muitas das questões abordadas a seguir - características das escolas-campo, dificuldades para a realização do estágio etc. - são compartilhadas em diversos modelos de provisão de estágio.

Portanto, mesmo que a experiência seja algo individual - e cada um dos sujeitos entrevistados e cada uma das IES analisadas possua suas próprias características - as reflexões que trazemos para esta pesquisa podem servir de inspiração e influência para diversos modelos de estágio proporcionados para a licenciatura em Matemática no Brasil.

Para esta pesquisa, ouvimos 20 sujeitos oriundos de 6 IES do Estado do Rio de Janeiro (todas elas públicas). Esse grupo de sujeitos é composto de professores que atuam em escolas públicas e privadas do Ensino Fundamental e Médio e tinham, quando entrevistados, no máximo 3 anos de formados (recém-egressos) e não realizaram nenhuma etapa do estágio sob supervisão dos autores. A técnica de amostragem utilizada foi a Bola de Neve (BOGDAN; BIKLEN, 1994), ou seja, os sujeitos contatados sugeriram participantes para as entrevistas. Todos os sujeitos contatados que satisfizeram os critérios de pesquisa e se dispuseram a realizar as entrevistas foram parte da pesquisa.

As entrevistas foram transcritas e foram atribuídos pseudônimos aos sujeitos que puderam retirar-se da pesquisa, sem qualquer prejuízo e a qualquer tempo antes da 


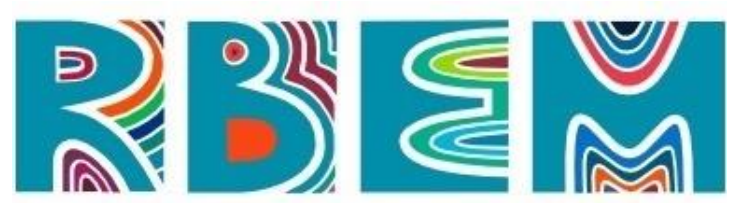

REVISTA BAIANA DE EDUCAÇÃO MATEMÁTICA

publicação, mesmo após a assinatura do termo de consentimento. Nenhum sujeito realizou este tipo de solicitação.

Para a análise das entrevistas, foi utilizado o software Atlas $\mathrm{Ti}^{2}$ como suporte à Análise de Conteúdo (BARDIN, 2004) da qual emergiram 14 categorias (após sucessiva recategorização) que, por proximidade, foram organizadas em seis eixos: as escolhas, a escola, o estágio acontecendo, as relações construídas, os sentidos percebidos pelos sujeitos e o passado no presente. O recorte desta pesquisa corresponde aos dois primeiros eixos. Silva (2019) apresenta a pesquisa completa, com descrição pormenorizada dos sujeitos, da análise das diversas categorias e eixos, bem como dos roteiros das entrevistas semiestruturadas.

\section{Quem fala conosco?}

Para entender quais são os limitantes e características do estágio supervisionado, precisamos primeiramente entender o papel e a dimensão da prática nos currículos da licenciatura. Gatti; Nunes (2009) mostram que, frequentemente, a dimensão da prática não é pensada como componente fundamental dos cursos de formação inicial. Como consequência, o estágio passa a ser uma seção desarticulada da formação. Com efeito,

as horas a eles referentes [aos estágios] são registradas como parte das estruturas curriculares, embora não se especifique como eles se realizam [...]. Não há especificação clara sobre como são realizados, supervisionados e acompanhados. Sobre a validade ou validação desses estágios também não se encontrou nenhuma referência. Não estão claros os objetivos, as exigências, formas de validação e documentação, acompanhamento, convênios com escolas das redes etc. Essa ausência nos projetos e ementas pode sinalizar que, ou são considerados totalmente à parte do currículo, o que é um problema, na medida em que devem integrar-se com as disciplinas formativas e com aspectos da educação e da docência, ou, sua realização é considerada como aspecto meramente formal (GATTI; NUNES, 2009, p. 21).

Com base na pesquisa, as autoras concluíram a Licenciatura em Matemática forma alunos com diferentes perfis: formação matemática profunda (foco no conteúdo matemático), formação pedagógica sem conexão com a formação matemática e poucos cursos com boa

\footnotetext{
${ }^{2} \mathrm{O}$ software pode ser adquirido e baixado em https://atlasti.com/
} 


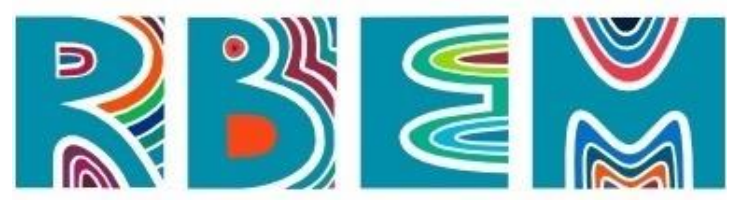

REVISTA BAIANA DE EDUCAÇÃO MATEMÁTICA

articulação com a educação matemática.

Interessante notar um paralelo entre o que é observado em Gatti; Nunes e as três concepções de estágio que são apresentadas em Pimenta; Lima (2012): (i) prática como imitação de modelos; (ii) prática como instrumentalização técnica; e (iii) a superação da dicotomia entre teoria e prática. A primeira, prática como imitação de modelos, entende o papel da prática como algo a ser esmiuçado por meio da profunda observação, tentando dotar os estagiários (futuros professores) de capacidades para o trabalho por meio de imitação da prática de docentes experientes. Já concepção da prática como instrumentalização técnica pressupõe que o estágio é local de fazer a aplicação da teoria. A escola-campo é local de experimentação e confirmação das teorizações produzidas no meio acadêmico e os estagiários são ensinados a usar instrumentos e técnicas. Por fim, a concepção de superação da dicotomia entre teoria e prática tem como caraterística a articulação entre teoria e prática, no campo de estágio, entendo a experiência de estágio como multidimensional, permeada por saberes de diversas fontes.

Licenciaturas, tanto com foco no conteúdo matemático quanto com formação pedagógica sem conexão com a formação matemática são caracterizadas por desarticulação entre os conhecimentos teóricos e os conhecimentos da prática. Defender a superação da dicotomia entre teoria e prática, bem como a articulação entre o conteúdo matemático e a educação matemática é favorecer uma formação que articule saberes de diversos meios, integradas ao desenvolvimento profissional docente. Veremos a seguir que as IES citadas neste trabalho também têm currículos que se aproximam/afastam dessas concepções e perfis.

Porém, para entender de que forma os sujeitos são atravessados pelo tempo e espaço do estágio - vindo a se tornar professores - é importante compreender de que forma eles passam por esta experiência. Para Larrosa (2015), a experiência é o que nos acontece, nos forma, transforma e afeta. A experiência não é regida pela lógica de ação, mas lógica de paixão: o sujeito da experiência é passional. A experiência é o que nos acontece, o que nos passa e, ao passar, nos forma e transforma, ela nos afeta de algum modo ao produzir afetos e deixar marcas.

Precisamos entender que o estágio é uma etapa da formação que possui um valor para os sujeitos, que se sentem imbuídos a compartilhar com os autores alguns elementos deste momento formativo. Por isso entender qual é o papel e a importância do estágio para a 


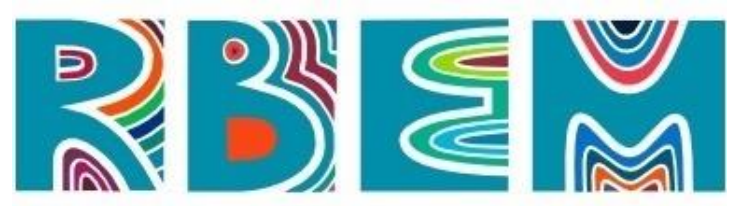

REVISTA BAIANA DE EDUCAÇÃO MATEMÁTICA

prática atual como docentes é também dar um valor a como estas experiências, refletidas e buriladas pelo tempo - mesmo que seja curto para nossos recém-egressos. O tempo que transforma a memória, valorizando certos elementos, certas emoções. Compreender as dimensões emocionais, individuais, únicas e íntimas de nossos entrevistados é também importante para colocar as conclusões deste trabalho em um contexto.

\section{Vozes que emergem dos dados}

Este trabalho é baseado na análise de conteúdo das entrevistas realizadas com 20 professores $^{3}$ recém egressos de 6 IES públicas do Estado do Rio de Janeiro (UA, UB, UC, UD, UE e UF). Para começar a entender e contextualizar a experiência de estágio dos sujeitos, vamos começar relatar resumidamente as características dos estágios nos documentos oficiais das IES. Levamos em consideração os documentos que estavam vigentes quando os entrevistados realizaram o estágio. Com as mudanças recentes nas normas das licenciaturas em matemática, são esperadas mudanças no peso e distribuição da prática no currículo. Sigamos a uma breve apresentação, IES por IES.

\section{UA}

O curso é composto de 3172,5 horas, das quais 405 correspondem ao Estágio Curricular Supervisionado de Prática de Ensino. Dessas horas do estágio, 81 horas para Encontros Semanais de Supervisão de Estágio e 324 horas para Atividades de Estágio. O PPC apresenta um direcionamento metodológico para essas atividades, que incluem desde o reconhecimento do contexto escolar (que corresponde, provavelmente, ao período de observação) até a elaboração e aplicação de um plano de estágio, além da avaliação. O estágio ocorre ao longo de três semestres, correspondendo às disciplinas Estágio Supervisionado I, II e III. O estágio pode ocorrer em escolas públicas ou privadas.

\section{UB}

\footnotetext{
3 Os sujeitos serão identificados, neste trabalho, por meio de pseudônimos oriundos da literatura. As características e histórias dos personagens não têm qualquer relação com os sujeitos.
} 


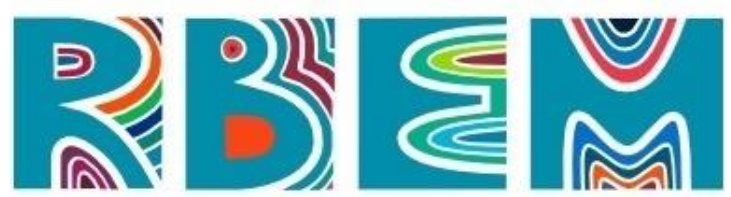

REVISTA BAIANA DE EDUCAÇÃO MATEMÁTICA

O estágio na UB é dividido em quatro disciplinas (Estágio Supervisionado I, II, III e IV), incluídas na matriz curricular do curso, com carga horária de 100 horas cada uma. Nessas 100 horas estão incluídas atividades na escola e fora dela, mas o texto não apresenta como essas horas efetivamente são distribuídas. Assim, são 400 horas de estágio de um total de 3160 horas. No Estágio Supervisionado I, o estagiário acompanha turmas de Educação Infantil, primeiro segmento do Ensino Fundamental ou de Formação de Professores ${ }^{4}$. No Estágio Supervisionado II, o estagiário deve acompanhar atividades do segundo segmento do Ensino Fundamental. O Estágio Supervisionado III, envolve atividades no Ensino Médio. Por fim, o Estágio Supervisionado IV é realizado em outras modalidades de ensino, sendo que no mínimo 30 horas devem ocorrer em Educação de Jovens e Adultos, Educação Especial ou Indígena. Já as 70 horas restantes podem ser cumpridas em espaços educativos não-escolares. Incluem-se nestas horas atividades discentes em programas e projetos, como extensão, PIBIC, PET, PIBID ou monitoria, podendo ser abatidas até 50 horas do estágio IV.

UC

O estágio da UC é dividido em 7 disciplinas, envolvendo três diferentes departamentos. A faculdade de educação é responsável por uma disciplina de $90 \mathrm{~h}$, sendo 30 minis delas teóricas e 60 efetivamente no campo de estágio. Além disso, há mais 3 estágios, ligados ao instituto de matemática, um com 30, outro com 60 e outro com 90 horas, que podem ocorrer em qualquer instituição conveniada e têm como atividades observação e coparticipação em salas de aula da educação básica. Por fim, há três estágios que ocorrem obrigatoriamente no Colégio de Aplicação da UC. Desta forma, estágio tem uma carga de 450 horas de efetivo trabalho em campo, de um total de 3160 horas mínimas (incluídas 200 horas de atividades acadêmico-científico-culturais).

\section{UD}

O estágio na UD é dividido em quatro disciplinas, cada uma delas com uma carga horária de 100 horas, cursadas nos quatro últimos semestres do curso. Não há, no plano pedagógico do curso uma menção de como essas horas são distribuídas. O curso tem um total

\footnotetext{
${ }^{4}$ Não está claro no texto, mas provavelmente a Formação de Professores aqui se refere a cursos de formação para professores das séries iniciais, os chamados Cursos Normais.
} 


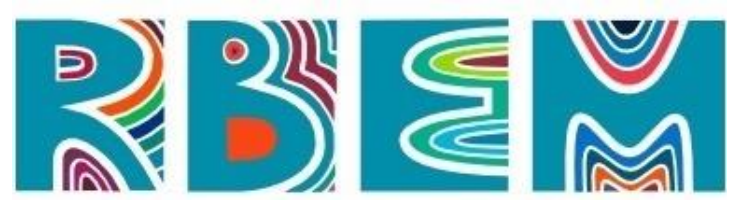

de 2932 horas/aula.

\section{UE}

O estágio na UE ocorre em Escolas Públicas ou instituições públicas de educação nãoformal e totaliza 400 horas divididas em três períodos, sendo que 100 delas podem ser computadas como atividades complementares. Desta forma, o estagiário pode estar apenas 300 horas no campo de estágio.

A carga horária do curso é de 2880 horas, incluídas 200 são de atividades acadêmicocientífico-culturais. O estágio ocorre com observação, coparticipação e regência e o Colégio de Aplicação é destacado como campo de estágio curricular, embora não seja único.

\section{UF}

A UF organiza a carga horária total de estágio em três disciplinas $(150+150+120$ horas) totalizando 420 horas de estágio dentro de um universo de 2960 horas (incluídas 200 horas de atividades complementares). O estágio é citado algumas vezes durante o PPC como espaço de prática e de saberes. Outra peculiaridade da UF é que os estágios não ocorrem nos últimos semestres do curso, de acordo com a grade (ao contrário de todas as outras IES) mas

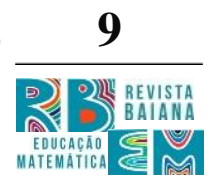
do $4^{\circ}$ ao $6^{\circ}$ período, em concomitância com disciplinas de caráter pedagógico. Isso pode permitir uma discussão das experiências ocorridas no estágio nestas disciplinas.

Ao colocar as IES em perspectiva, pudemos notar diferenças: na quantidade de horas reservadas ao estágio, de 400 (UB, UD e UE) a 480 (UC); na contagem das horas eram contadas, incluindo a carga da disciplina (UA e UC) ou carga horária total no campo; na quantidade de escolas em que o estágio deve se realizar; nos diversos níveis de ensino; na integração do estágio no curso de licenciatura; e no papel da escola-campo na formação inicial. É importante notar que os Colégios de Aplicação são importantes campos de estágio em algumas das IES analisadas, o que será aprofundado mais à frente.

Com estes apontamentos, podemos passar agora à análise das categorias oriundas das entrevistas, com base nos eixos as escolhas e a escola.

\section{Ouvindo e interpretando}




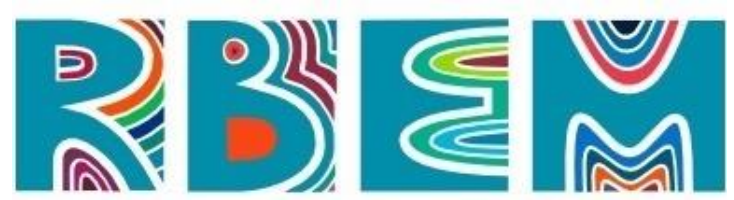

REVISTA BAIANA DE EDUCAÇĀO MATEMÁTICA

\section{Eixo 1: As escolhas}

Para a seleção do campo de estágio, nossos sujeitos foram limitados por uma série de fatores. Alguns deles são ligados à instituição formadora, como alternativas de escola conveniadas, obrigatoriedade de realização de uma parte do estágio em uma modalidade de ensino e/ou em uma escola-campo específicas etc. Existem também condições que são ligadas aos sujeitos, como limitação de tempo disponível, adequação à carga horária das disciplinas que estão sendo cursadas na graduação, crenças e valores sobre a importância dessa etapa para a formação, desejo de conhecer diferentes "realidades escolares" etc. Queremos entender quais são os critérios efetivos que foram decisivos para que nossos entrevistados realizassem estágio nos seus campos. Como veremos, a maior parte dos entrevistados teve grande liberdade para escolher seu campo de estágio ou mesmo o professor-supervisor com quem realizou o estágio.

Nesse eixo foram identificadas duas categorias: distribuição dos tempos de estágio e critério de seleção da escola-campo. Sobre a distribuição do tempo de estágio, é preciso fazer algumas ressalvas. Estamos trabalhando com memórias de sujeitos, que podem ser imprecisas e fortemente influenciadas por situações que ocorreram concomitantemente ao estágio. Com isso, muito embora confiemos no bom senso e na boa fé dos entrevistados para nos dar depoimentos verdadeiros sobre suas trajetórias, sabemos que essas limitações podem estar presentes.

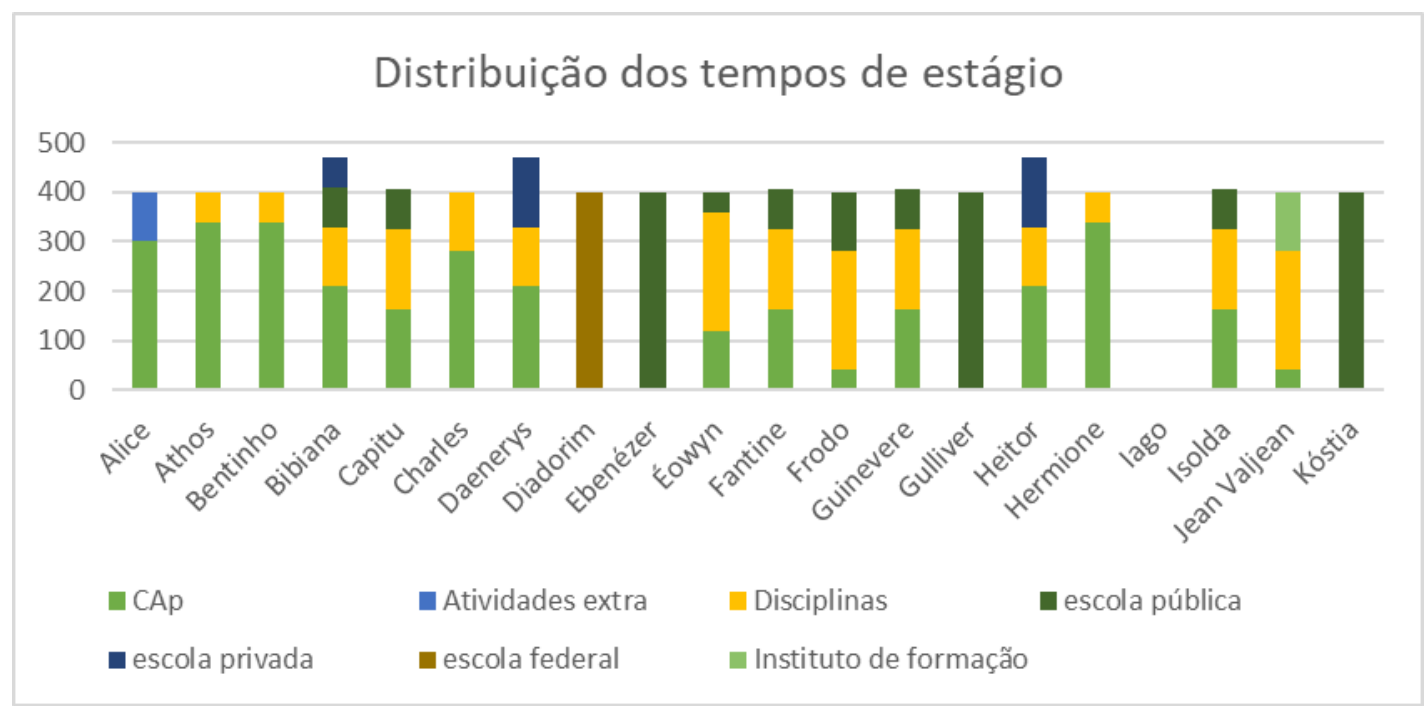

Figura 1 - Distribuição dos tempos de estágio. Fonte: Dados de pesquisa 


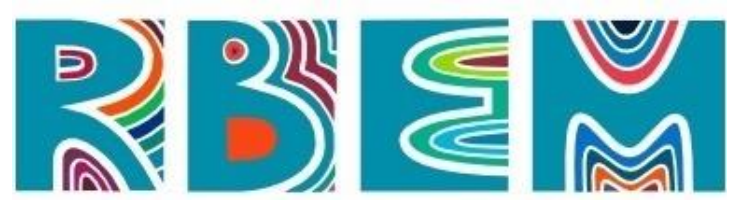

REVISTA BAIANA DE EDUCAÇÃO MATEMÁTICA

A categoria distribuição dos tempos de estágio teve um total de sete unidades de registro, correspondentes à maneira como o tempo de estágio foi efetivamente utilizado pelo aluno de licenciatura segundo suas lembranças. Isso significa que não foi questionado se as informações eram conflituosas com o que foi dito por outro estagiário da mesma IES, nem se isso difere do que está proposto na distribuição esperada de carga horária das disciplinas do curso. Como regra de enumeração, foi considerado o tempo em cada atividade. As unidades de registro são a) horas em Colégio de Aplicação; b) atividades extraclasse que contaram como horas; c) carga horária da disciplina de estágio; d) estágio realizado em Escola Pública da Rede Municipal ou Estadual; e) estágio realizado em Escola Privada; f) estágio realizado em Escola Pública Federal; e g) estágio realizado em instituto de educação e formação de professores da educação básica, as escolas normais.

Quando algum entrevistado não se lembrou do tempo de alguma atividade, usamos como base os documentos oficiais das IES para determinar, aproximadamente, a carga horária. Para nossa análise, utilizaremos a Figura 1 que resume graficamente os dados da Tabela 1.

Podemos perceber uma prevalência dos Colégios de Aplicação com campos de Estágio. Esta situação pode ser considerada como uma peculiaridade do Rio de Janeiro, onde há variedade de IES públicas e delas organizarem os estágios, senão com obrigatoriedade nos Colégios de Aplicação, com algum peso ou recomendação das IES. Zimmer (2017) aponta que a preferência por CAps para a realização do estágio também ocorre em outras Universidades Federais ao longo do Brasil.

Tabela 1 - Distribuição dos tempos de estágio.

\begin{tabular}{|c|c|c|c|c|c|c|c|c|c|c|}
\hline & IES & CAp & $\begin{array}{l}\text { Atividades } \\
\text { extra }\end{array}$ & Disciplinas & $\begin{array}{l}\text { Escola } \\
\text { pública }\end{array}$ & $\begin{array}{l}\text { Escola } \\
\text { privada }\end{array}$ & $\begin{array}{l}\text { Escola } \\
\text { federal }\end{array}$ & $\begin{array}{l}\text { Instituto } \\
\text { de } \\
\text { formação }\end{array}$ & Total & $\begin{array}{c}\text { Em } \\
\text { campo }\end{array}$ \\
\hline Alice & UE & 300 & 100 & & & & & & 400 & 300 \\
\hline Athos & UE & 340 & & 60 & & & & & 400 & 340 \\
\hline Bentinho & UE & 340 & & 60 & & & & & 400 & 340 \\
\hline Bibiana & UC & 210 & & 120 & 60 & 60 & & & 450 & 330 \\
\hline Capitu & UA & 216 & & 81 & 108 & & & & 405 & 324 \\
\hline Charles & UF & 280 & & 120 & & & & & 400 & 280 \\
\hline Daenerys & UC & 210 & & 120 & & 120 & & & 450 & 330 \\
\hline Diadorim & UE & & & & & & 400 & & 400 & 400 \\
\hline Ebenézer & UD & & & & 400 & & & & 400 & 400 \\
\hline Éowyn & UD & 300 & & & 100 & & & & 400 & 400 \\
\hline Fantine & UA & 216 & & 81 & 108 & & & & 405 & 324 \\
\hline Frodo & UD & 40 & & 240 & 120 & & & & 400 & 160 \\
\hline Guinevere & UA & 164 & & 160 & 81 & & & & 405 & 245 \\
\hline Gulliver & UB & & & & 400 & & & & 400 & 400 \\
\hline Heitor & UC & 210 & & 120 & & 120 & & & 450 & 330 \\
\hline
\end{tabular}




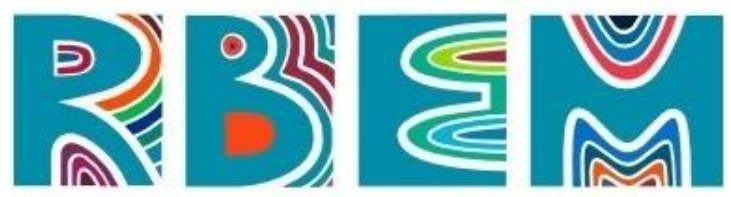

REVISTA BAIANA DE EDUCAÇÃO MATEMÁTICA

\begin{tabular}{|l|l|l|l|l|l|l|l|}
\hline Hermione & EU & 340 & 60 & & 400 & 340 \\
\hline Iago & UB & & & & & 400 & 220 \\
\hline Isolda & UA & 74 & 180 & 146 & 120 & 400 & 160 \\
\hline Jean & UD & 40 & 240 & & 400 & 400 \\
\hline Kóstia & UB & & & 400 & & 400 \\
\hline
\end{tabular}

Fonte: Dados de Pesquisa

Podemos notar também que apenas na UC houve uma parte do estágio em instituições privadas. Com isso, quase a totalidade do tempo de estágio dos sujeitos de nossa amostra ocorreu em escolas da Rede Pública ou foi contada na instituição formadora, com horas de disciplinas ou atividades complementares.

Também percebemos o peso desigual das relações entre o tempo contado das disciplinas das IES como parte da carga horária de estágio. Para alguns, o tempo da disciplina no tempo de estágio sequer foi contado (como é o caso de Alice, Diadorim, Ebenézer, Éowyn, Gulliver e Kóstia). Já segundo a lembrança de Frodo, em cada uma das quatro disciplinas de estágio, contaram 60 horas de aula na IES e 40 horas de estágio (160 de estágio e 240 de disciplina). Isso gerou grandes discrepâncias no tempo efetivamente em campo, conforme podemos ver na Figura 2. Destacamos os casos de Éowyn, Jean, Guinevere, Isolda e Frodo, em que as mudanças, retirando a carga horária das disciplinas, são mais visíveis.

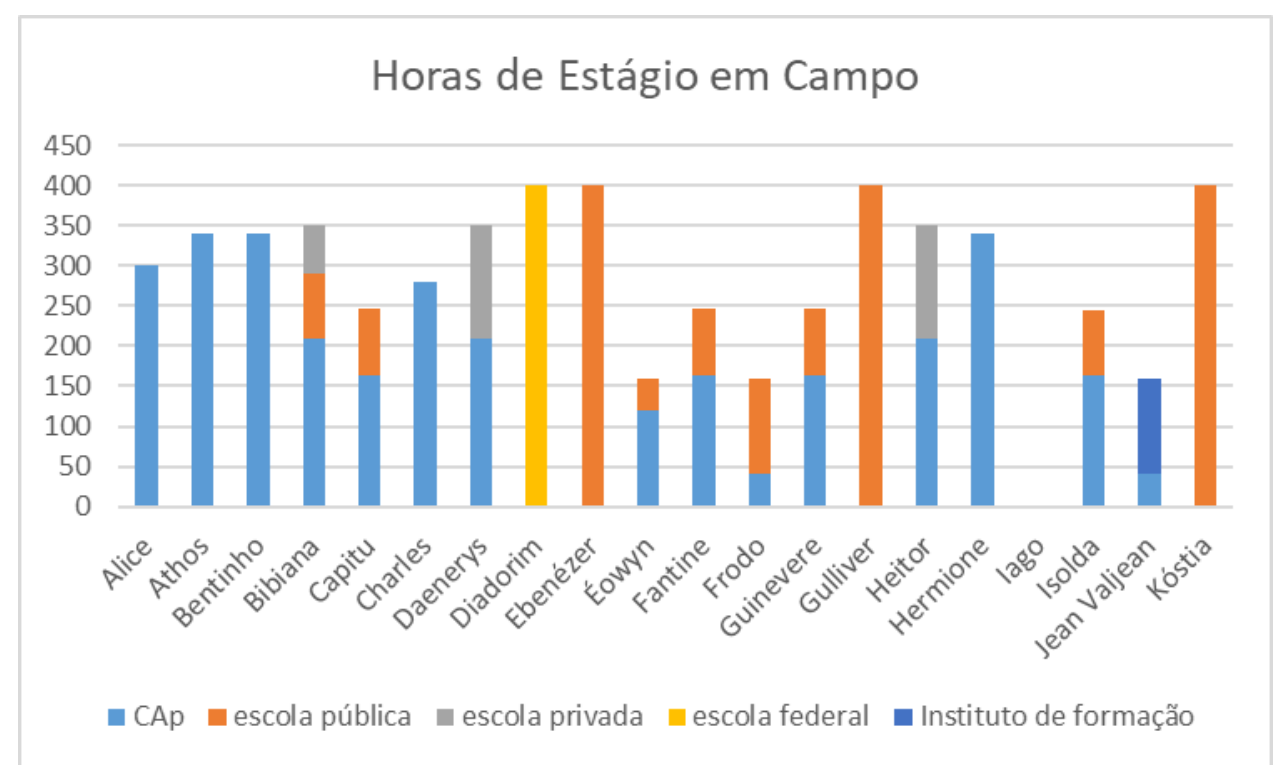

Figura 2 - Distribuição das horas de estágio em campo, segundo entrevistados. Fonte: Dados da pesquisa

\footnotetext{
${ }^{5}$ Os dados de Iago não constam nesta tabela, pois ele não tinha certeza da distribuição da carga de estágio. Ele disse ter realizado o estágio em várias escolas, mas não ter certeza de quanto tempo passou em cada uma delas.
} 


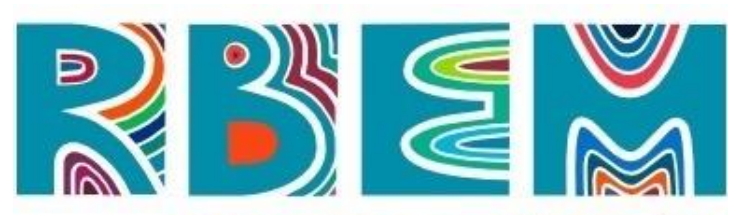

REVISTA BAIANA DE EDUCAÇÃO MATEMÁTICA

A Figura 1 também nos ajuda a perceber que os estagiários tiveram experiências diversificadas em seu estágio. Estarem em uma única escola-campo foi a exceção, não a regra. Ebenézer, Gulliver e Kóstia, embora tenham feito o estágio apenas em Escolas Públicas, realizaram o mesmo em mais de uma escola-campo. A exceção são a UE e a UF onde todos realizaram estágio em uma escola-campo só.

Outra exceção é Iago. Sua experiência de estágio foi errática, dividida ao longo de vários semestres, em várias escolas-campo. Nem mesmo ele sabia em quantas escolas-campo atuou, já que ele começou algumas vezes o estágio e depois perdeu essas horas. Desse modo, optamos por deixar sua linha de dados vazia, entendendo que seus dados não são confiáveis para essa categoria, mas serão importantes para outras que virão a seguir.

A categoria critérios de seleção da escola-campo, possui 9 unidades de registro: a) quando o estagiário escolheu o campo por indicação de professores da universidade ou colegas de curso (indicação); b) quando o critério principal de escolha foi formativo (formação); c) quando o motivo alegado foi a proximidade de casa ou do curso (proximidade); d) quando o estagiário já conhecia o professor-supervisor e decidiu realizar estágio com ele (professor); e) quando decidiu ir para a escola que estudou (estudou); f) quando o campo de estágio é obrigatório (obrigatório); g) quando a escola tem um horário conveniente para o estagiário (horário); h) quando já sabe que a burocracia vai ser menor (burocracia); e i) quando já realizou ou realiza projeto na escola-campo (projeto).

Tabela 2 - Critérios de Seleção para a Escola-Campo.

\begin{tabular}{|c|c|c|c|c|c|c|c|c|c|}
\hline & Indicação & Formação & Proximidade & Professor & Estudou & Obrigatório & Horário & Burocracia & Projeto \\
\hline Alice & Sim & & & & & & & & \\
\hline Athos & Sim & Sim & & & & & & & \\
\hline Bentinho & Sim & & Sim & & & & & & \\
\hline Bibiana & & & & Sim & Sim & & & & \\
\hline Capitu & & & & & Sim & & Sim & & \\
\hline Charles & & Sim & & & & Sim & & & \\
\hline Daenerys & & & Sim & & & Sim & & Sim & \\
\hline Diadorim & Sim & & Sim & & & & & & \\
\hline Ebenézer & & & Sim & & & & & & \\
\hline Éowyn & & & Sim & & & & & & \\
\hline Fantine & & Sim & Sim & & & & & & \\
\hline Frodo & & & Sim & & & & & & \\
\hline Guinevere & & Sim & Sim & Sim & & & & & \\
\hline Gulliver & & Sim & Sim & & Sim & & & & Sim \\
\hline Heitor & & & & & Sim & Sim & & & \\
\hline Hermione & & Sim & & & & & & & Sim \\
\hline Iago & & & Sim & & & & & & \\
\hline Isolda & & & Sim & Sim & Sim & & & & \\
\hline Jean & & & Sim & & & & & & \\
\hline
\end{tabular}




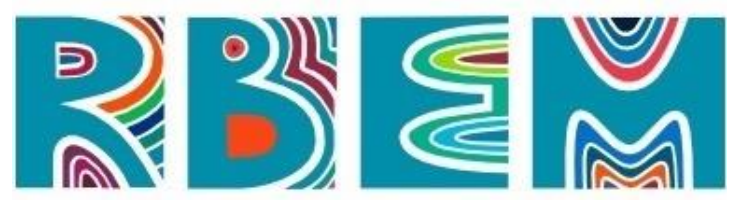

REVISTA BAIANA DE EDUCAÇÃO MATEMÁTICA

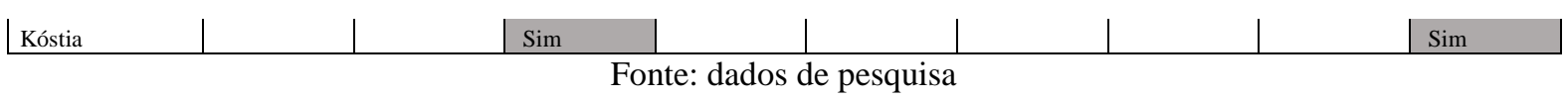

As unidades de registro foram enumeradas pelo critério de presença/ausência e podem ser visualizadas na Tabela 2. Podemos perceber que a unidade proximidade é a mais comum (13 registros em 20 ou 65\%). Algumas hipóteses para isso são: a dificuldade financeira que faz com que muitos estagiários escolham um campo próximo para economizar; e/ou a comodidade de se deslocar pouco da IES para o campo de estágio e vice-versa. Perlin (2018, p. 51) também aponta que o principal critério de escolha da escola-campo é a proximidade da residência ou da universidade.

A segunda unidade mais presente é formação (7 registros ou 35\%) mostrando que esses estagiários pensaram em um lugar que poderia ter uma experiência formativa melhor como critério preferencial de escolha. A terceira unidade foi estudou (5 registros ou 25\%), o que mostra a importância afetiva da escola em que o estagiário estudou, fazendo com que ele decida voltar a esse lugar, agora como professor em formação, com um novo olhar para um lugar que é familiar.

A unidade indicação nos mostra a influência da IES na escolha do campo de estágio, já que dá ao estagiário referências de locais valorizados e que, espera-se, ofereçam uma boa formação. De fato, essa pode ser uma preocupação:

\begin{abstract}
Athos: Foi uma orientação da professora de prática de ensino inicialmente [...] na época isso foi apresentado como uma das opções que seriam mais interessantes no sentido de aproveitamento do curso uma vez que é uma instituição, [...] com professores que, pelo discurso que a gente teve no início, teriam uma visão pensado para a formação de professores mesmo... no sentido de ter mais atenção, ter momentos de discussão [...]. Então eu acabei escolhendo essa opção por achar que eu queria aproveitar o melhor que a instituição poderia oferecer e essa escola pareceu uma opção interessante apesar da distância.
\end{abstract}

Por fim, destacamos a unidade obrigatório, não só pela presença (já que a UC realmente obriga que uma parte do seu estágio ocorra no CAp e a UF só tinha uma única escola conveniada), mas também pela ausência, justamente porque Bibiana não citou esse como um critério importante, mesmo estudando na UC. Destacamos que escolas que realizam projetos (pesquisa, extensão, PIBID) costumam ser escolhidas como campo de estágio. Mais uma vez, o motivo para isso pode ser a comodidade, já que os estagiários já teriam que se deslocar para esses campos para a realização de suas atividades.

Finalizando o eixo as escolhas, podemos perceber que os estagiários representados 


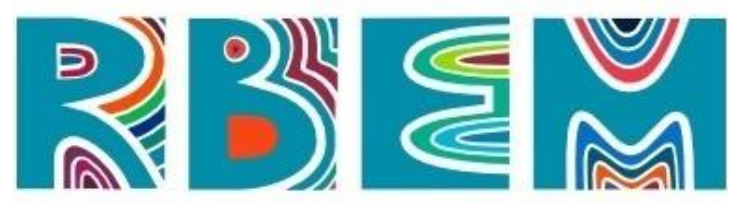

REVISTA BAIANA dE EDUCAÇÃO MATEMÁTICA

nessa amostra têm uma tendência a escolher escolas-campo próximas de suas casas ou IES, majoritariamente Escolas Públicas (incluindo colégios de aplicação).

Zimmer (2017), aponta que frequentemente é a IES quem define qual será a escolacampo, com base em critérios como proximidade da universidade, formação ou até mesmo segurança.

[fala de um dos entrevistados] O que leva escolher a escola é o local, penso nas necessidades dele, até mesmo de segurança física. Eu parto de mim, das minhas raízes e das mesmas dificuldades que encontrei nos três primeiros anos de faculdade em que voltava para casa a pé porque não tinha dinheiro e se eu tivesse esquecido isso eu os massacraria e acredito que por isso estabeleço uma boa relação e sou até convidado para paraninfo (ZIMMER, 2017, p. 183).

Feldkercher enumera vários critérios que podem ser utilizados para a escolha da escola-campo:

\footnotetext{
Os principais motivos de escolha das escolas foram: ter vínculo com a escola através do PIBID, ter algum conhecido trabalhando na escola, ter vínculo através de projetos de monitoria, ser a primeira escola encontrada com vaga disponível, ser a escola mais próxima de sua casa, ser a escola que sobrou ou ser a escola para a qual foi sorteado (FELDKERCHER, 2011, p. 95).
}

Já Eugênio (2015) mostra que os critérios apontados são: a realização de estágio em uma escola que estudou; a proximidade/acessibilidade do campo e conhecer e ter contato com a professora-supervisora. Percebemos assim que os critérios de seleção da escola-campo encontrados nesta pesquisa têm paralelos com a literatura.

Esse eixo nos mostrou como foi o tempo que os estagiários se dedicaram ao estágio e quais os motivos de escolha do espaço. No eixo seguinte, vamos falar de uma outra dimensão: o espaço, a escola, o lugar. Continuemos a contar a nossa história.

\section{A escola}

O eixo a escola é composto por 3 categorias: características da escola-campo; acolhimento e critério de seleção da turma. Com isso, objetivamos dar ao processo de entrada no campo de estágio três olhares: a escola; a entrada do estagiário nesse ambiente e a seleção da turma.

A categoria características da escola-campo possui oito unidades de registro, sete delas são enumeradas pela presença/ausência e uma unidade (sem detalhes) explicita quando 


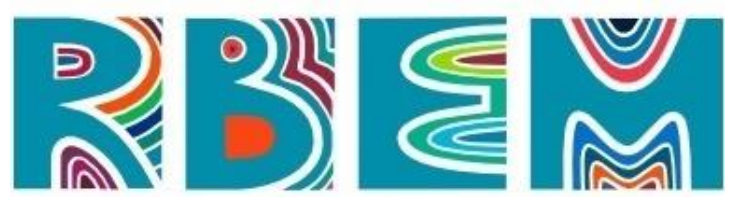

REVISTA BAIANA DE EDUCAÇÃO MATEMÁTICA

o respondente não descreveu alguma das escolas-campo. As unidades de registro e sua enumeração podem ser acompanhadas na Tabela 3. Como alguns dos entrevistados estagiaram em mais de uma escola, utilizaremos um esquema de números para identificar qual escola-campo corresponde a cada marcação. Na última coluna (tipo de escola-campo) estão descritas, em ordem de citação do entrevistado, as escolas cuja enumeração está nas colunas 2 (escola preparada) a 9 (sem detalhes). Quando o entrevistado não disse se a escola era municipal, estadual ou federal, a escola-campo foi enumerada como pública.

Foi difícil estabelecer detalhes das escolas-campo, sobretudo quando o entrevistado atuou em várias delas. As lembranças se confundem e, como se passaram alguns anos desde o estágio, é natural que haja algum grau de incerteza acerca do que efetivamente aconteceu em cada campo. Como regra para enumeração, foram consideradas todas as referências à descrição do campo. Por exemplo, na tabela 3 observamos que Ebenézer realizou estágio em quatro escolas, todas municipais, e que as percebeu todas como carentes de recursos. Já Bibiana realizou estágio em três escolas, sendo que a segunda (por ordem de citação)é uma escola pública considerada pro ela preparada e que havia tempo de reunião na grade para encontro com o professor supervisor de estágio.

Da tabela 3, podemos perceber algumas características que estão presentes nas escolas do mesmo tipo. Os CAps são usualmente descritos como escolas preparadas para receber os estagiários, com alunos motivados.

\begin{abstract}
Éowyn: Bom, o ambiente era propício, fantástico para o estagiário né, os alunos eram acostumados com a presença dos estagiários, os professores gostavam dos estagiários. É aconteceu uma coisa muito peculiar eu diria por que a minha professora do ensino médio era a professora do CAp e a gente teve uma troca bacana assim, ela até me [ininteligível] um pouco no sentido de fazer questão para prova, mas foi legal, mas foi bem legal essa experiência.
\end{abstract}

Tabela 3 - Características da Escola-Campo.

\begin{tabular}{|c|c|c|c|c|c|c|c|c|c|}
\hline & $\begin{array}{c}\text { Escola } \\
\text { Preparada }\end{array}$ & $\begin{array}{c}\text { Tempo para } \\
\text { reunião }\end{array}$ & $\begin{array}{c}\text { Carente de } \\
\text { recursos }\end{array}$ & $\begin{array}{c}\text { Alunos } \\
\text { motivados }\end{array}$ & $\begin{array}{c}\text { Alunos } \\
\text { disciplinados }\end{array}$ & $\begin{array}{c}\text { Vulnerabili- } \\
\text { dade social }\end{array}$ & $\begin{array}{c}\text { Direção } \\
\text { engajada }\end{array}$ & $\begin{array}{c}\text { Sem } \\
\text { detalhes }\end{array}$ & Tipo de Campo \\
\hline Alice & 1 & & & 1 & & & & CAp \\
\hline Athos & 1 & 1 & & 1 & & & 1 & CAp \\
\hline Bentinho & & & & 1 & 1 & & & & Fed. \\
\hline Bibiana & 2 & 2 & 1 & & & & & 3 & CAp, Púb., Priv. \\
\hline Capitu & 1 & & 2 & 1 & & & 2 & Fed., Est \\
\hline Charles & 1 & 1 & & 1 & & & & & CAp \\
\hline Daenerys & 1 & & & 1 & & & & 2 & CAp, Priv. \\
\hline Diadorim & 1 & & & & 1 & & & & Fed. \\
\hline Ebenézer & & & $1,2,3,4$ & & & & & & Mun. \\
\hline Éowyn & 1 & 1 & 2 & & & 2 & & & CAp e Mun. \\
\hline Fantine & 2 & & 1 & 2 & & & & & Mun., Fed. \\
\hline Frodo & 1 & & 2 & 1 & & 2 & & & CAp, Mun. \\
\hline
\end{tabular}




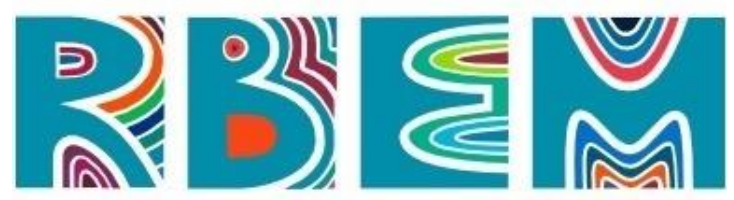

REVISTA BAIANA DE EDUCAÇÃO MATEMÁTICA

\begin{tabular}{|c|c|c|c|c|c|c|c|c|}
\hline Guinevere & 1 & & & 1 & & & 2 & CAp e Mun. \\
\hline Gulliver & & & 1,2 & & 1,2 & & 3,4 & Pub. \\
\hline Heitor & 1 & & & 1,2 & & & & CAp, Priv. \\
\hline Hermione & 1 & 1 & & 1 & & & & CAp \\
\hline Iago & & & $1,2,3$ & & $1,2,3$ & & & Pub. \\
\hline Isolda & 1 & & 2,3 & 1 & 2,3 & & & Fed., Est., Mun. \\
\hline Jean & 1 & & & 1 & & 2 & & Mun. e Est. \\
\hline Kóstia & & & $1,2,3$ & & & & & Pub. \\
\hline
\end{tabular}

Fonte: dados de pesquisa

Já as Escolas Públicas são descritas como carentes de recursos, muitas delas estando em locais de vulnerabilidade social. Mesmo assim, muitos entrevistados valorizaram esses lugares e as experiências que foram oportunizadas neles, como veremos em outras categorias a seguir.

Outro dado interessante é que alguns dos entrevistados não descreveram algumas de suas escolas-campo (coluna sem detalhes da Tabela 2). Isso aconteceu principalmente porque ou eram apenas campo de observação (e eles não se lembram de mais detalhes) ou porque a experiência nesses campos foi superficial e os momentos marcantes ocorreram em outro espaço. Isso pode indicar que certos tipos de experiências de estágio falham em deixar lembranças duradouras ou significativas para serem rememoradas depois de algum tempo.

A carência de recursos, presente em boa parte dos campos de estágio também foi fonte de aprendizados. Isolda, por exemplo, cita o caso de uma aluna surda em uma escola sem recursos que foi acompanhada por ela em seu estágio:

\footnotetext{
$\mathrm{Na}$ turma do terceiro ano [da escola-campo estadual] tinha uma aluna que ela era surda, então assim, foi marcante porque eu percebia o interesse e a vontade dela ali, mas infelizmente [a escola] não proporcionava os recursos que ela precisava, entendeu? O professor não podia e nem sabia falar em Libras né, mas, mesmo assim, às vezes ela caminhava mais do que os alunos que não possuíam esse tipo de dificuldade, né?
}

Percebemos que havia tanto falta de recursos materiais quanto humanos para que a aluna fosse incluída. A falta de um intérprete de Libras ou de uma formação do professor para o trabalho em Libras foi notada por Isolda, mas foi importante para que ela entendesse como trabalhar com inclusão nessas situações.

Os entrevistados que realizaram estágio em Escolas Públicas valorizam a experiência nesses campos como um local para conhecer suas dificuldades, mas também suas potencialidades. Essas experiências em situações reais são, atualmente, vistas como importantes para seu trabalho. Um dos destaques é a liberdade para propor ações e projetos 


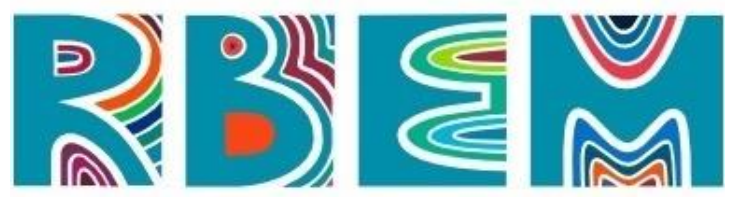

REVISTA BAIANA DE EDUCAÇÃO MATEMÁtICA

nas escolas públicas, o que não ocorre em algumas escolas particulares:

Diadorim: Sim cara, [...] no estado [meu local de trabalho] eles dão bastante liberdade, não tem assim alguém te restringindo a alguma coisa, alguém te fiscalizando para saber se você está dando o currículo. Eu tento sempre fazer um trabalho assim bem bacana com o pessoal, até porque você não pode ser muito... na linha ali de rigoroso, de pôr quadro, giz, caneta porque pô eu atendo muito o pessoal da comunidade, pessoal muito carente, então se você chegar muito assim, vou dizer a gíria ne, muito cheio de marra, [...] de dar aquela aula, "porra ${ }^{6}$ eu estou aqui e você está aí, vai ser o quadro, a caneta e pronto e acabou"... cara, você não vai dar aula entendeu? Você pode estar ali dentro da sala, mas você não vai dar aula entendeu?

A segunda categoria que trataremos nesse eixo é o acolhimento. Esta categoria emergiu das entrevistas e buscava entender como foi o processo de acolhida nas escolascampo, na visão dos estagiários.

Organizar os dados dessa categoria foi particularmente difícil, pois muitos dos estagiários estiveram em mais de um campo. Nem todos descreveram o acolhimento em todos os campos, ou por falta de lembrança ou porque não consideraram essa uma questão relevante para sua experiência de estágio.

Foram identificadas as seguintes unidades de registro: recepção na escola, burocracia e recepção em sala, que foram enumeradas na escala péssimo, ruim, neutro, bom, ótimo ou sem resposta, conforme a Tabela 4. Foi importante perceber que há movimentos diferentes de percepção quanto ao acolhimento na escola e na sala de aula onde ocorre o estágio.

Tabela 4 - Acolhimento.

\begin{tabular}{|l|c|c|c|}
\hline & Recepção na escola & Burocracia & Recepção em Sala \\
\hline Alice & Boa & Boa & Sem resposta \\
\hline Athos & Boa & Boa & Boa \\
\hline Bentinho & Excelente & Boa & Boa \\
\hline Bibiana & Neutro & Neutro & Sem resposta \\
\hline Capitu & Boa & Boa & Sem resposta \\
\hline Charles & Boa & Boa & Excelente \\
\hline Daenerys & Boa & Neutro & Sem resposta \\
\hline Diadorim & Excelente & Boa & Sem resposta \\
\hline Ebenézer & Ruim & Neutro & Ruim \\
\hline Éowyn & Boa & Neutro & Sem resposta \\
\hline Fantine & Ruim & Sem resposta & Boa \\
\hline Frodo & Boa & Sem resposta & Neutra \\
\hline Guinevere & Boa & Ruim & Neutra \\
\hline Gulliver & Boa & Boa & Sem resposta \\
\hline
\end{tabular}

\footnotetext{
${ }^{6}$ Em nosso compromisso de manter a linguagem dos entrevistados, optamos por não censurar nem mesmo os palavrões usados. Achamos que o uso deles no texto mostra também a intensidade do que tem se falado e é, portanto, informação relevante da citação.
} 


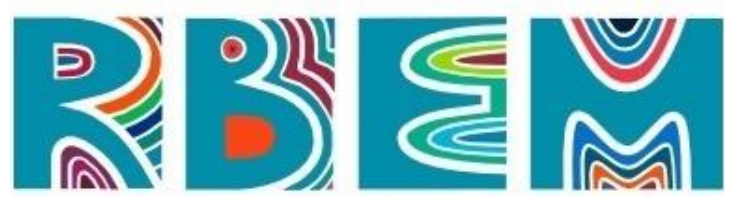

REVISTA BAIANA DE EDUCAÇÃO MATEMÁTICA

\begin{tabular}{|l|c|c|c|} 
Heitor & Boa & Boa & Boa \\
\hline Hermione & Boa & Boa & Excelente \\
\hline Iago & Bom & Ruim & Bom \\
\hline Isolda & Bom & Bom & Bom \\
\hline Jean & Excelente & Boa & Boa \\
\hline Kóstia & Boa & Neutro & Boa \\
\hline
\end{tabular}

Fonte: dados de pesquisa

A partir da análise da enumeração, podemos ver que, em geral, o acolhimento é percebido como bom ou ótimo em quase todos os campos de estágio, sendo menos burocráticos nos CAps. Podemos inferir que escolas que costumam receber estagiários têm uma preparação melhor e, com isso, tendem a ter um melhor acolhimento. Isso pode ser exemplificado pela fala de Daenerys:

Daenerys: No CAp já é tradicional aquilo: todo mundo já sabe como funciona, então foi supertranquilo, todos os professores já sabem como funciona. Até a questão de burocracia... aí eu fiz estágio em outras duas [escolas] [...]. Uma delas já tava acostumada a receber estagiário, então foi mais fácil, me acolheram bem, já sabiam até falar o que que precisava ou não, documentação. Em uma outra eu fui a primeira estagiária que eles receberam nessa situação, então foi um pouco mais difícil, mas não tive problema pra ser recebida, aceitaram, só não sabiam muito bem a parte burocrática mesmo como funcionava.

Também notamos que existe uma questão burocrática em algumas escolas, sobretudo públicas. Os entrevistados relataram que precisaram ir à coordenadoria de ensino algumas vezes para resolver pendências, o que pôde atrapalhar o início do estágio. Paes (2017) apresenta exatamente os mesmos pontos como importantes para o acolhimento dos estagiários nas escolas-campo. Um de seus entrevistados diz:

Quando eu cheguei, me apresentei como estagiário e a escola me recebeu muito bem. Eu me lembro até da diretora no pátio falando assim: Vocês são estagiários? Sejam bem-vindos. Assim, muito simpática, muito receptiva com a gente. E aquilo gerou um clima de conforto, a gente ficou muito à vontade na escola para observar, para conversar com os funcionários. Então, assim, a escola nos recepcionou muito bem. [...]

O que foi um pouco conturbado pra mim foi a recepção de estágio enquanto disciplina, na forma como está organizada. Eu não esperava tanta burocracia: assinaturas, relatório, contrato, seguro [...]. Eu imaginava uma certa burocracia, porém um pouco mais reduzida, pensei que seria um processo muito mais de troca com os colegas, com os professores, eu esperava talvez uma coisa mais dinâmica (Mário - Licenciatura em Letras - 2015). (PAES, 2017, p. 113)

Também notamos que muitos entrevistados não consideraram a recepção em sala de aula como uma parte do acolhimento. De fato, não foi perguntado especificamente sobre a recepção em sala, mas apenas seus acolhimentos, com base em seus próprios critérios. Isso 


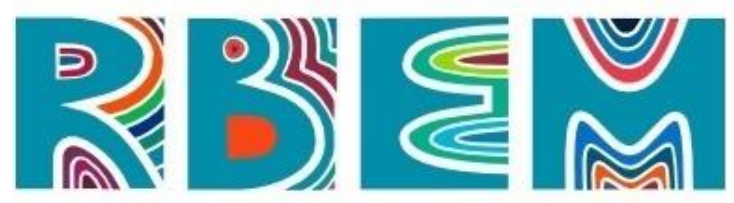

REVISTA BAIANA DE EDUCAÇÃO MATEMÁTICA

fez com que questões como a recepção na direção/secretaria e as dificuldades na entrega de documentos fossem mais presentes do que efetivamente o acolhimento em sala de aula. Essa recepção pode não ser boa e vista pela escola-campo ou pelo professor-supervisor como invasiva, sobretudo em estágios de observação, em que não existe uma troca entre estagiário e professor-supervisor, o que pode ser exemplificado por esse trecho da transcrição de Ebenézer:

\footnotetext{
Entrevistador: E você acha que a escola estava preparada para te receber como estagiário?

Ebenézer: Olha, cara, nunca está, né, nunca está. Sempre quando a gente chega como estagiário eles ficam olhando torto, porque a gente anota tudo, né, a gente anota tudo que o professor faz em sala... Então provavelmente era tudo muito disfarçado, né, pra que pudesse mostrar que tá fazendo bem e a gente sabe que não é a realidade da rede pública. Eu mesmo estudei em rede pública e sei como é que é.
}

Isso aponta para uma necessidade de deixar mais claro para o professor-supervisor qual é o seu papel na formação do estagiário de modo que ele não se sinta vigiado ou avaliado, mas como um elemento importante na formação, oportunizando experiências práticas e possibilidades ancoradas na realidade escolar. De toda forma, é esperado que a presença de um estagiário gere algum grau de mudança no campo de estágio:
A presença do estagiário na sala de aula causa uma certa desestabilização nos alunos da classe, diante do elemento novo, e insegurança no professor em relação à sua própria imagem. Ele se sente questionado no que diz respeito aos seus conhecimentos e pedagógicos, à sua competência e à forma como se relaciona com seus alunos. Por isso, tenta se preservar, "esquivar-se" de determinadas situações, seja se omitindo, seja tentando passar uma outra imagem que não corresponde à sua, para negar aquela que lhe está sendo imputada, a partir da percepção dele e do estagiário, que estão em campos diferentes. (BARREIRO; GEBRAN, 2006, p. 98)

Essas questões possuem impactos no acolhimento que devem ser consideradas no planejamento das ações que ocorrem no estágio. Caso o professor-supervisor de estágio se compreenda como alguém que está atuando na formação de professores e não como alguém a ser avaliado, é mais provável que ele acolha e valorize a relação com o estagiário, com impactos positivos para o acolhimento.

Vamos à última categoria desse eixo, Critério de seleção da turma, que é composta de 6 unidades de registro, enumeradas pela presença ou ausência, conforme a Tabela 5.

As unidades de registro foram: a) conteúdo, quando o estagiário escolhe a turma que vai realizar o estágio conforme o conteúdo que tem mais interesse ou afinidade; b) série, 


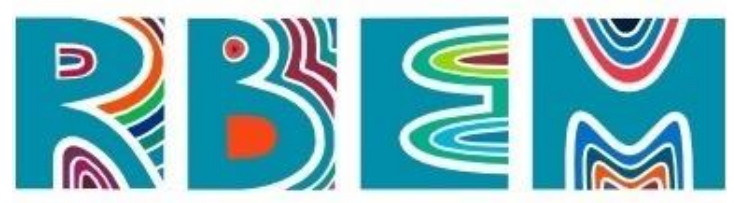

REVISTA BAIANA DE EDUCAÇÃO MATEMÁTICA

quando a série é determinante na escolha; c) o horário, quando o estagiário escolhe a turma com base no horário de trabalho/faculdade ou para se adequar a outros estágios que esteja realizando concomitantemente; d) conhecido, quando escolhe um professor-supervisor que já conhece pessoalmente antes do começo do estágio; e) projeto, quando o estagiário está interessado em um projeto já em realização pelo professor-supervisor; e f) critério do campo, quando os estagiários são alocados pela escola-campo e não têm autonomia para selecionar a turma que vai realizar estágio.

Tabela 5 - Critérios de seleção da turma.

\begin{tabular}{|c|c|c|c|c|c|c|}
\hline & Conteúdo & Série & Horário & Conhecido & Projeto & Critério do Campo \\
\hline \multicolumn{7}{|l|}{ Alice } \\
\hline \multicolumn{7}{|l|}{ Athos } \\
\hline \multicolumn{7}{|l|}{ Bentinho } \\
\hline \multicolumn{7}{|l|}{ Bibiana } \\
\hline \multicolumn{7}{|l|}{ Capitu } \\
\hline \multicolumn{7}{|l|}{ Charles } \\
\hline \multicolumn{7}{|l|}{ Daenerys } \\
\hline \multicolumn{7}{|l|}{ Diadorim } \\
\hline \multicolumn{7}{|l|}{ Ebenézer } \\
\hline \multicolumn{7}{|l|}{ Éowyn } \\
\hline \multicolumn{7}{|l|}{ Fantine } \\
\hline \multicolumn{7}{|l|}{ Frodo } \\
\hline \multicolumn{7}{|l|}{ Guinevere } \\
\hline \multicolumn{7}{|l|}{ Gulliver } \\
\hline \multicolumn{7}{|l|}{ Heitor } \\
\hline \multicolumn{7}{|l|}{ Hermione } \\
\hline \multicolumn{7}{|l|}{ Iago } \\
\hline \multicolumn{7}{|l|}{ Isolda } \\
\hline \multicolumn{7}{|l|}{ Jean Valjean } \\
\hline Kóstia & & & & & & \\
\hline
\end{tabular}

Fonte: dados de pesquisa.

O critério mais lembrado (12 de 20 ou $60 \%$ ) foi conhecido. Isso pode significar uma tendência a buscar professores-regentes que foram professores dos estagiários na Educação Básica (casos de Heitor e Éowyn, por exemplo) ou mesmo na graduação. Alguns motivos foram alegados para isso, como admiração por esse profissional (caso de quem quis fazer com professor marcante na Educação Básica), desejo de voltar à escola que estudou, curiosidade, mais intimidade com o professor-supervisor ou, nos estágios realizados em institutos federais que possuem curso de licenciatura, porque o professor da graduação também dá aula no ensino técnico, o que facilita questões burocráticas.

Heitor: O professor que eu escolhi para fazer o estágio também foi meu professor do ensino médio, ele também era bem rigoroso e eu fiz quatro estágios no [colégio particular] e três estágios no CAP, que era os estágios obrigatórios.

O segundo critério em ordem de citação é o horário, com 6 referências. Adequar o horário às disciplinas é importante para adequar a carga horária curso com o estágio, 


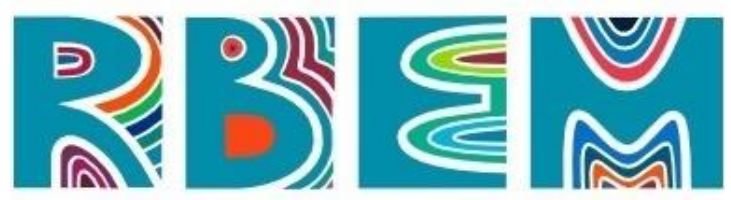

REVISTA BAIANA DE EDUCAÇÃO MATEMÁTICA

particularmente no curso diurno. Outros já trabalhavam durante a graduação, o que interfere no tempo disponível para a realização do estágio, fazendo, inclusive, com que eles necessitassem realizar estágio durante as férias.

Notamos também que existem campos que não permitem a escolha, devido, principalmente, à grande quantidade de estagiários. Isso pode levar a experiências ruins, como a de Heitor, que relatou que realizou estágio em uma turma muito indisciplinada e com uma professora que era mal avaliada pela turma:

\footnotetext{
Heitor: Eu dei uma aula para turma [..] do oitavo ano [...] e a professora [...] era muito mal avaliada no geral e dentre os alunos, dentre os estagiários, dentre alguns professores [...] em termos de qualidade mesmo, de ensino, de comportamento e eu tive que dar uma aula para essa turma. [...] A turma era horrível no sentido de comportamento né?

[...] chegou a minha vez de dar aula naquela turma, eu elaborei minha aula, ela viu minha aula com antecedência, ela me pediu uma modificação ou outra, modifiquei de acordo com o que ela considerou o correto. Dei a minha aula, consegui controlar a turma, dado o nível de comportamento da turma que tocava o terror na aula dela, principalmente. Controlei o aluno que era o pivô de toda a bagunça lá, consegui chamar ele para mim, botei ele para resolver exercício no quadro, orientei ele durante o exercício, a turma parou e prestou atenção, dei apoio a ele, alguns zoaram e tudo mais.
}

A escola em questão era um CAp, mas a professora-regente, segundo relato de Heitor, não tinha muita experiência docente e estava em um contrato temporário. Isso pode ter influenciado negativamente na experiência do estágio, o que mostra que mesmo escolas preparadas podem ser desafiadoras para a efetivação de possibilidades formativas.

Outra contribuição relevante para a escolha é a existência de projetos. Alguns entrevistados relataram ter ficado interessados em atividades de pesquisa ou extensão realizadas pelos professores-regentes em seus locais de trabalho. Isso pode significar, para alguns estagiários, uma valorização dos saberes da prática sendo aplicados efetivamente em situações de ensino. Por exemplo, Hermione diz que escolheu fazer estágio nessa turma "na verdade era por conta do projeto, eu precisava assistir as aulas do [professor-supervisor] por conta do projeto e tinha que assistir também a aula do ensino fundamental". Para Hermione, esse projeto foi importante também, pois garantia uma bolsa, que ela precisou para conseguir se deslocar da IES para a escola-campo.

Os entrevistados nos mostraram que, enquanto estagiários, buscaram campos preferencialmente preparados para recebê-los (o que concorda com as conclusões do eixo as escolhas). Também vimos que há uma preferência de realização de estágios com professores 


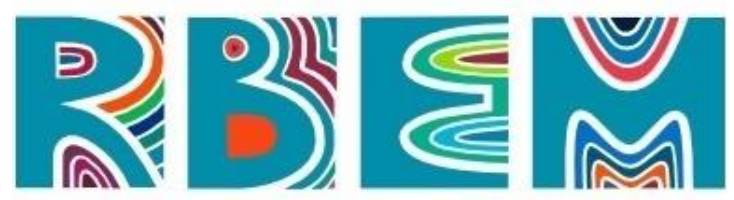

REVISTA BAIANA DE EDUCAÇÃO MATEMÁTICA

conhecidos, o que pode significar que a relação construída entre estagiário e professorsupervisor deve ser mais bem analisada.

Entretanto, não podemos esquecer que critérios formativos não preponderam nas escolhas, tanto do campo, quanto da turma, no conjunto entrevistado. Questões mais práticas, como horário, proximidade e relação estabelecida são mais citados e, dessa forma, podem ser vistos como importantes. Isso indica que os campos de estágio devem equilibrar as oportunidades formativas a serem oferecidas com a flexibilidade para se adequar às possibilidades (ou impossibilidades) dos estagiários.

\section{Ecos}

A análise das entrevistas mostra que os estudantes levam em consideração, quando na escolha do campo, critérios práticos, como a proximidade e a menor burocracia, critérios emocionais, como voltar à escola que esteve ou estar com um professor-supervisor com quem já tem alguma relação e também critérios formativos. Podemos destacar que escolas que têm maior preparação para serem campos de estágio, como os colégios de aplicação, têm maior procura por terem pontos de interseção com alguns destes critérios.

Silva (2019) mostra que a preparação do campo de estágio, aliada a vínculos emocionais criados entre estagiário e professor-supervisor deixam memórias mais nítidas que se configuram em influências mais presentes na prática de professores em começo de carreira.

Vale destacar que mesmo escolas com vulnerabilidade social podem ser bons campos de estágio. Estratégias de acolhimento, aliadas a um corpo docente que entenda a supervisão de estágio como etapa fundamental da formação de novos professores podem ser bons laboratórios para a prática docente.

Além disso, é importante que o estágio não seja apenas uma etapa obrigatória e desarticulada do curso de licenciatura (o local da prática). Uma prática situada e problematizada ao currículo dá um sentido mais profundo à experiência do estágio que pode ser utilizada para formar professores mais preparados para o trabalho na sala de aula.

Por fim, destacamos a importância de incrementar as pesquisas no campo do estágio. Embora o recorte desta pesquisa apresente uma visão muito particular, situada em seis IES do Estado do Rio de Janeiro, entendemos que as reflexões apresentadas neste trabalho podem 


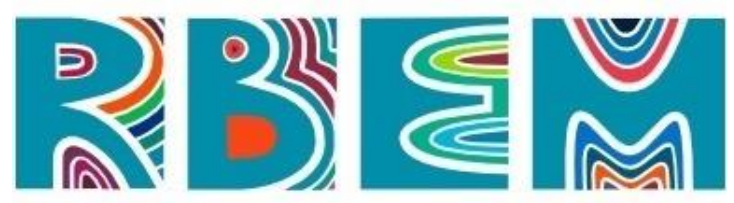

REVISTA BAIANA DE EDUCAÇÃO MATEMÁTICA

servir de suporte a investigações semelhantes em outros contextos.

\section{Referências}

BARDIN. L. Análise de conteúdo. Lisboa: Editora Edições 70, 2004.

BARREIRO, I. M. de F.; GEBRAN, R. A. Prática de ensino e estágio supervisionado na formação de professores. São Paulo: Avercamp, 2006.

BRASIL. Resolução $N^{o} 2$, de $1^{o}$ de julho de 2015. Define as Diretrizes Curriculares Nacionais para a formação inicial em nível superior (cursos de licenciatura, cursos de formação pedagógica para graduados e cursos de segunda licenciatura) e para a formação continuada. Disponível em http://portal.mec.gov.br/index.php?option=com_docman\&view=download\&alias=17719-rescne-cp-002-03072015\&Itemid=30192. Acessado em: 29 mar. 2019.

CYRINO, M. C. C. T.; PASSERINI, G. A. Reflexões sobre o estágio supervisionado do curso de Licenciatura em Matemática da Universidade Estadual de Londrina. In: CINELLI, Marlene. R.; SILVA, Ileizi F. O estágio na licenciatura: a formação de professores e a experiência interdisciplinar na Universidade Estadual de Londrina. Londrina: UEL, 2009. v. 1, p. 125-144.

EUGÊNIO, K. S. O. Estágio supervisionado na formação inicial: os laços formativos entre estágio e escola. Fortaleza, 2015. 114 f. Dissertação (Mestrado em Educação) - Faculdade de Educação, Universidade Estadual do Ceará, 2015.

FELDKERCHER, N. O estágio na formação de professores presencial e a distância: a experiência do curso de matemática da UFPEL. Pelotas, 2011. 139 f. Dissertação (Mestrado em Educação) - Faculdade de Educação, Universidade Federal de Pelotas, 2011.

FIORENTINI, D.; PASSOS, C. L. B.; LIMA R. C. R. (org.) (2016). Mapeamento da pesquisa acadêmica brasileira sobre o professor que ensina Matemática: Período 2001 - 2012. FEUnicamp: Campinas, E-book (488 p.). Disponível em: https://www.fe.unicamp.br/pffe/pagina_basica/58/e-book-mapeamento-pesquisa-pem.pdf. Acesso em: 06 dez. 2020.

GATTI, B. A.; NUNES, M. M. R. Formação de professores para o ensino fundamental: estudo de currículos das licenciaturas em pedagogia, língua portuguesa, matemática e ciências biológicas. São Paulo: FCC/DPE, 2009. v. 29, p. 1-155

GONÇALVES JÚNIOR, M. A. Narrativas Sobre o Estágio da Licenciatura Em Matemática - perscrutações sobre si. Campinas: Mercado das Letras, 2016.

LOPES, A. R. L. V.; PAIVA, M. A. V.; PEREIRA, P. S.; POZEBON, S.; CEDRO, W. L. Estágio Curricular Supervisionado nas licenciaturas em Matemática: reflexões sobre as pesquisas brasileiras. Zetetike, v. 25, n. 1, p. 75-93, jan./abr. 2017. 


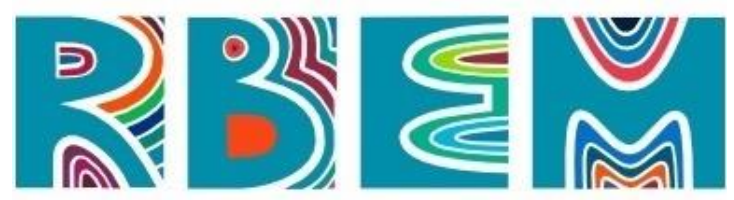

MOREIRA, P. C. $3+1$ e suas (In)Variantes (Reflexões sobre as possibilidades de uma nova estrutura curricular na Licenciatura em Matemática). Bolema, Rio Claro, v. 26, n. 44, p. 1137 1150 dez. 2012. Disponível

em: http://www.scielo.br/scielo.php?script=sci_arttext\&pid=S0103636X2012000400003\&lng=en\&nrm=iso. Acesso em: 17 jun. 2017.

PAES, E. F. Mobilizações no processo de estágio supervisionado na formação inicial de professores: reflexos de experiências no instituto federal fluminense. Campinas, 2017. Tese (Doutorado em Educação) - Faculdade de Educação, UNICAMP, 2017.

PERLIN, P. Constituindo-se professor de matemática: relações estabelecidas no estágio curricular supervisionado, determinantes da aprendizagem da docência. Santa Maria, 2018. Tese (Doutorado em Educação) - Faculdade de Educação, Universidade Federal de Santa Maria, 2018.

PIMENTA, S. G.; LIMA, M. S. L. Estágio e Docência. 7. ed. São Paulo. 2012.

ZIMMER, I. Estágio Curricular Supervisionado na Licenciatura em Matemática: Um componente curricular em discussão. 2017. 220f. Tese (Doutorado em Educação Matemática) - Universidade Federal de Santa Catarina, Florianópolis, 2017.

Artigo submetido em: 10/12/2020

Artigo aceito em: 18/01/2021 